\title{
Pola Asuh Anak dalam Perspektif Pendidikan Islam
}

\author{
Padjrin \\ Program Pascasarjana \\ Universitas Islam Negeri Raden Fatah Palembang, Indonesia \\ Email: dhapadjrin@gmail.com
}

\begin{abstract}
Abstrak
Orang tua dalam keluarga memiliki peran dan tanggung jawab terhadap anaknya. Setiap orang tua ingin mempunyai anak yang berkepribadian akhlak mulai atau yang saleh. Untuk mencapai keinginan tersebut, orang tua diharapkan untuk mengoptimalkan peran dan tanggung jawab sebagai orang tua terhadap anaknya. Mengasuh dan mendidik anak yang dilakukan orang tua dengan berbagai macam pola asuh seperti demokratis; otoriter; permisif; dan penelantar (acuh tak acuh). Pola asuh yang menjadi sorotan saat ini adalah pola asuh otoriter yang identik dengan tanpa kasih sayang, kekerasan, mengengkang anak, dan memaksa. Pola ini akan menjadikan batin anak tersiksa, krisis kepercayaan, potensinya tidak berkembang secara optimal, hingga mengalami trauma dan sebagainya. Pola asuh seperti ini sangat bertentangan dengan ajaran Islam yang mengawali konsep kasih sayang dalam mendidik anak. Islam sebagai agama solutif terhadap permasalahan yang terjadi dalam keluarga tentang bagaimana mendidik anak sesuai dengan usia dan masa pertumbuhan dan perkembangan anak. Pola asuh ini telah dipraktikkan oleh Rasulullah Saw. Adapun pola asuh tersebut, yaitu: membimbing cara belajar sambil bermain pada jenjang usia 0-7 tahun; menanamkan sopan santun dan disiplin pada jenjang usia 7-14 tahun; dan ajaklah bertukar pikiran pada jenjang usia 14-21 tahun, dan sesudah itu lepaskan mereka untuk mandiri.
\end{abstract}

Kata Kunci: Pola Asuh Anak, Pendidikan Islam

Keluarga merupakan insitusi terkecil dalam masyarakat. Menurut Duval (1997) dalam (Supartini, 2004) mengemukakan bahwa keluarga adalah sekumpulan orang yang dihubungkan oleh ikatan perkawinan, adopsi, dan kelahiran yang bertujuan menciptakan dan mempertahankan budaya yang umum, meningkatkan perkembangan fisik, mental, emosional dan sosial setiap anggota. Selanjutnya, Bailon (1978) dalam (Achjar, 2010) berpendapat bahwa keluarga sebagai dua atau lebih individu yang berhubungan karena hubungan darah, ikatan perkawinan atau adopsi, hidup dalam satu rumah tangga, berinteraksi satu sama lain dalam peranannya dan menciptakan serta mempertahankan budaya.

Keluarga sebagainya unsur terkecil dalam masyarakat terdiri atas dua atau lebih individu yang meliputi ayah, ibu, dan anak. Mereka dihubungkan dengan ikatan perkawinan dan darah. Mereka juga berinteraksi satu sama lain untuk menghasilkan budaya dan meningkatkan perkembangan fisik, mental, emosional, dan sosial bagi setiap anggota keluarga.

Islam memandang bahwa kedua orang tua memiliki tanggung jawab terhadap pertumbuhan fisik dan perkembangan psikis anaknya bahkan lebih dari itu membebaskan anaknya dari siksaan api neraka. Sebagaimana firman Allah Swt.: 


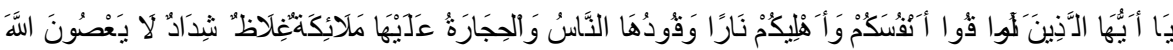

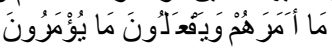
Artinya: Hai orang-orang yang beriman, peliharalah dirimu dan keluargamu dari api neraka yang bahan bakarnya adalah manusia dan batu; penjaganya malaikat-malaikat yang kasar, keras, dan tidak mendurhakai Allah terhadap apa yang diperintahkan-Nya kepada mereka dan selalu mengerjakan apa yang diperintahkan. (Q.S. at-Tahrim: 6)

Ayat di atas menjelaskan bahwa setiap individu termasuk orang tua harus berusaha membebaskan diri dan keluarganya dari siksaan api neraka. Orang tua dalam keluarga terutama ibu harus memberikan asupan makanan terutama makanan halal dan baik serta mendidik yang sesuai dengan usianya dan tentunya mengarah kepada pembentukan akhlak anak. Hal di atas sangat erat dengan bagaimana pola dalam mengasuh anak.

Pola asuh adalah cara yang digunakan dalam usaha membantu anak untuk tumbuh dan berkembang dengan merawat, membimbing dan mendidik, agar anak mencapai kemandiriannya (Kamus Bahasa Indonesia, 2000). Pada dasarnya pola asuh adalah suatu sikap dan praktek yang dilakukan oleh orang meliputi cara memberi makan pada anak, memberikan stimulasi, memberi kasih sayang agar anak dapat tumbuh kembang dengan baik (Jus'at, 2000).

Orang tua dalam mengasuh dan mendidik anak sering sekali tidak diimbangi dengan pengetahuan tentang bagaimana mendidik anak yang dicontohkan oleh Rasulullah Saw. Akibat kurangnya pengetahuan tersebut, mereka lupa akan tanggung jawab sebagai orang tua dan mendidik pun dengan pola yang tidak dibenarkan dalam Islam. Fenomana kesalahan mengenai pola asuh anak saat ini sering sekali terjadi, seperti dengan kekerasan fisik dan mental, terlalu bebas, dan sebagainya. Perlu diketahui oleh orang tua bahwa pola asuh mereka sangat mempengaruhi perubahan perilaku atau kepribadian anaknya. Jika diasuh dengan memperhatikan pola asupan makanan dan mendidik yang benar maka akan mempengaruhi kepribadian anak menjadi anak yang soleh. Begitu juga sebaliknya, apabila dididik dengan kekerasan maka anaknya menjadi anak yang krisis kepercayaan, kurang dalam intelengensinya dan sebagainya.

Anak sholeh merupakan harapan semua orang tua. Anak sholeh terbentuk karena adanya perhatian orang tua terhadap asupan makanan dan pola asuh yang benar dalam Islam. Rasulullah Saw. bersabda:

Artinya: "Anak yang shaleh adalah bunga surga” (al-Hadits)

$$
\text { الولد الصالح ريحانة من رياحين الجنة }
$$

\section{Peran dan Tanggung Jawab serta Pola Asuh Anak oleh Orang Tua dalam Perspektif Pendidikan Islam}

Peran dan Tanggung Jawab Orang Tua terhadap Anak

Islam memandang bahwa keluarga mempunyai peranan penting dalam pendidikan, baik dalam lingkungan masyarakat Islam maupun non-Islam. Karena keluarga merupakan 
tempat pertumbuhan anak yang pertama di mana dia mendapatkan pengaruh dari anggotaanggotanya pada masa yang amat penting dan paling kritis dalam pendidikan anak, yaitu tahun-tahun pertama dalam kehidupanya (usia pra-sekolah). Sebab pada masa tersebut apa yang ditanamkan dalam diri anak akan sangat membekas. Sebagaimana Rasulullah Saw. bersabda:

Artinya: Ibu adalah tempat belajar yang pertama (al-Hadits).

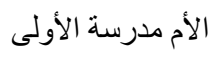

Orang tua dalam keluarga memiliki peran dan tanggung jawab terhadap anak. Peran dan tanggung jawab tersebut bertujuan agar supaya anaknya dapat tumbuh dan berkembang sesuai dengan usianya, mampu bersosial, dan menjadi anak yang berkepribadian sholeh.

Menurut Jalaluddin (2002: 4-6), anak yang saleh tidak dilahirkan secara alami. Mereka memerlukan bimbingan dan pembinaan yang terarah dan terprogram secara berkesinambungan. Dan tanggung jawab terhadap itu semua terletak pada kedua orang tuanya masing-masing. Bimbingan tersebut dengan tiga prinsip, yaitu: 1) prinsip teologis; 2) prinsip filosofis; dan 3) prinsip paedagogis, yang terintegrasi dalam suatu bentuk tanggung jawab terhadap anak. Sejalan dengan itu prinsip dimaksud, membimbing anak pada hakikatnya bertumpu pada tiga upaya, yaitu: memberi teladan, memelihara, dan membiasakan anak sesuai dengan perintah.

Pertama, memberi teladan. Tugas yang pertama ini orang tua berperan sebagai suri teladan bagi anaknya. Sebelumnya menjadi teladan, orang tua hendaknya memahami dan mengamalkannya terlebih dulu. Inilah sikap yang dicontohkan oleh Rasulullah Saw. Pengamalan terhadap ajaran agama oleh orang tua secara tidak langsung telah memberikan pendidikan yang baik terutama akhlak. Orang tua harus mendidik anaknya dengan akhlak mulia. Menurut Jalaluddin (2014), akhlak sangat berkaitan dengan Kholiq (Allah Swt) yang berbeda dengan moral. Artinya, erat kaitan dengan penghambaan diri atau ibadah kepada Allah Swt.

Pendidikan akhlak dalam keluarga merupakan komponen utama dalam membentuk kepribadian anak yang saleh. Hal ini sesuai dengan tugas Rasulullah Saw. dan pola pendidikan yang diterima oleh Rasulullah. Rasulullah bersabda:

إنما بعثت لأتم مكا رم الأخلاق

Artinya: Sesungguhnya Aku (Muhammad) di utus ke muka bumi ini untuk menyempurnakan akhlak manusia. (al-Hadits)

أدبني ربي فأحسن تأديبي

Artinya: "Tuhanku telah mendidikku dengan pendidikan yang sangat sempurna". (alHadits)

Orang tua saat ini lebih sibuk membimbing intelektual anaknya dengan menyuruh anaknya bimbingan belajar bahasa Inggris, IPA, bahasa Mandarin, dan lain sebagainya. Mereka lupa bahkan masa bodoh terhadap pendidikan akhlak anak di rumah. Mereka tidak menyadari, mengapa Rasulullah Saw. dipuji, hidupnya dalam lindungan Allah, dan 
menjadi teladan umat dunia?. Jawabannya adalah karena akhlak. Bahkan Allah Swt. memuji Rasulullah Swt. dalam firmannya:

$$
\text { و إنك لعلى خلق عظيم }
$$

Artinya: "Sungguh engkau memiliki akhlaq yang sangat tinggi”. (Q.S. al-Qalam: 4)

Pendidikan akhlak dalam keluarga sangatlah dibutuhkan dan menjadi solusi saat ini. Akhlak tersebut sebagai benteng pertahanan anak dari pengaruh budaya asing yang sangat merusak moral anak. Apalagi tidak melewati proses identifikasi budaya, akan lebih berbahaya terhadap kepribadian anak.

Kedua, memelihara anak. Tanggung jawab ini fokus pada pemeliharaan fisik melalui makanan dan minuman dan pengembangan potensi anak. Makanan dan minuman harus menjadi perhatian orang tua karena untuk kelancaran pertumbuhan fisik anak.

Menurut Jalaluddin (2002: 7), makanan dan minuman seyogyanya memenui persyaratan halal (hukumnya) dan thayyib (bahannya). Halal dari segi mencari dan mendapatkannya seperti berdagang, menjadi guru, dan berbisnis. Thayyib dari segi kandungan gizinya seperti nasi, daging, jagung, susu, tempe, tahu atau yang dikenal dengan makanan empat sehat lima sempurna. Makanan dan minuman yang halal dan thayyib agar diperhatikan dan sebagai syarat pokok dalam pertumbuhan dan perkembangan anak. Sebagaimana Allah Swt. berfirman:

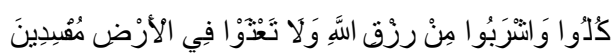

Artinya: Makanlah dan minumlah rezeki (yang diberikan) Allah, dan janganlah berkeliaran di muka bumi ini dengan berbuat kerusakan. (Q.S. al-Baqarah: 60)

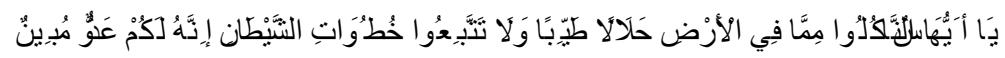

Artinya: Hai sekalian manusia, makanlah yang halal lagi baik dari apa yang terdapat di bumi, dan janganlah kamu mengikuti langkah-langkah syaitan; karena Sesungguhnya syaitan itu adalah musuh yang nyata bagimu. (Q.S. al-Baqarah: 168)

Kedua ayat di atas menjelaskan bahwa manusia diperintah untuk mencari makan dan minum yang bersumber dari Allah Swt di manapun dan kapanpun dengan syarat sesuai dengan kebutuhan atau tidak berlebihan. Selanjutnya dalam pencarian rizki Allah dianjurkan memperhatikan dari ke-halal-an dan ke-thayyib-annya. Setan terus menggoda manusia agar tidak memperhatikan kedua hal tersebut. Salah satu proses pencarian rizki yang tergoda oleh langkah setan adalah melalui praktek riba, perjudian, korupsi, merampok, dan lain sebagainya.

Makanan dan minuman ikut mempengaruhi kepribadian anak terutama pembentukan akhlak. Ironis saat ini, para orang tua mencari rizki melalui proses yang tidak dibenarkan dalam Islam seperti korupsi, padahal anak merupakan anugerah terbaik dari Allah Swt. yang harus dijaga dan dipeliharan sebaik mungkin. Misalnya, apabila pejabat yang terbukti oleh pengadilan melakukan korupsi sebanyak 100 pejabat. Setiap pejabat mempunyai tiga anak, maka jumlah 300 anak. 300 anak secara tidak langsung menjadi bibit koruptor baru 
di masa yang akan datang. Contoh dekat saja, ayahnya koruptor kasus pengadaan alQur'an dan anaknya juga terlibat dalam kasus tersebut.

Selanjutnya, orang tua bertanggung jawab terhadap perkembangan potensi anaknya. Potensi dalam Islam dikenal dengan konsep fitrah. Islam memandang bahwa setiap anak yang dilahirkan ke muka bumi ini memiliki potensi yang harus dikembangkan. Rasulullah Saw. bersabda:

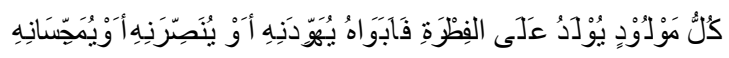

Artinya: Setiap anak yang lahir dalam keadaan fitrah, maka kedua orang tuanyalah yang akan menjadikan anak itu Yahudi, Nasrani, dan Majusi. (al-Hadits)

Mengenai potensi al-Ghazali berpendapat bahwa anak adalah masih suci dan kosong, ia selalu menerima apapun yang ditanamkan kepadanya (Kurniawan, 2011: 92). Pendapat ini, 13 abad kemudian dikembangkan oleh filsuf Inggris John Locke (1704-1932) menjadi teori "tabula rasa" atau "optimisme pedagogis". "Tabula rasa", yakni anak lahir di dunia bagaikan kertas putih yang bersih. Pengalaman empirik yang diperoleh dari lingkungan akan berpengaruh besar dalam menentukan perkembangan anak (Barnabib, 1997: 26). Pengalaman yang diperoleh anak dalam kehidupan sehari-hari didapat dari dunia sekitarnya yang berupa stimulant-stimulan. Stimulasi ini berasal dari alam bebas ataupun diciptakan oleh orang dewasa dalam bentuk program pendidikan.

Jalaluddin (2014) menjelaskan fitrah dapat dimaknai suci, potensi berupa fisik dan psikis, dan kesadaran untuk melakukan kebaikan dan keburukan. Potensi tersebut dapat terbentuk dan berkembang oleh pengaruh dari luar yang disebut dengan karakter.

Pendidikan yang diberikan oleh orang tuanya sangat mempengaruhi pembentukan kepribadian anaknya, apabila rangsangan tersebut positif maka akan positif pula begitu juga sebaliknya. Ibn Miskawih menjelaskan bahwa watak atau karakter dapat berubah sesuai dengan rangsangan yang diberikan melalui pendidikan.

Ketiga, membiasakan anak sesuai dengan perintah agama. Tugas ini fokus pada pembiasaan aturan agama kepada anak. Aturan agama yang berkaitan dengan syariat dan sistem nilai dalam bermasyarakat.

Perintah agama haruslah dilakukan oleh orang tua melalui proses pelatihan atau pembiasaan. Pembiasaan tersebut berkaitan dengan akhlak baik kepada Allah Swt., kedua orang tua, dan orang lain. Ibn Miskawih (1967: 9) dalam kitabnya Thabiz al-Akhlaq, menjelaskan bahwa akhlak adalah keadaan jiwa yang mengajak atau mendorong seseorang untuk melakukan perbuatan-perbuatan tanpa dipikirkan dan diperhitungkan sebelumnya.

Pandangan Miskawih di atas diikuti juga oleh al-Ghazali, akhlak adalah sesuatu yang menetap dalam jiwa dan muncul dalam perbuatan dengan mudah tanpa memerlukan pemikiran terlebih dahulu. Akhlak bukanlah perbuatan, kekuatan, dan ma'rifah. Akhlak adalah "haal" atau kondisi jiwa dan bentuknya bathiniyah (Rohayati, 2011: 12).

Dengan kata lain akhlak adalah keadaaan jiwa yang mendorong timbulnya perbuatanperbuatan secara spontan. Sikap jiwa atau keadaan jiwa seperti ini terbagi menjadi dua; ada yang berasal dari watak (bawaan) atau fitrah sejak kecil dan ada pula yang berasal dari 
kebiasaan latihan. Pembiasaan dengan syariat seperti sholat, puasa, dan sebagainya. Pembiasaan dengan sistem nilai berkaitan erat dengan akhlak anak seperti makan dan minum pakai tangan kanan, berbicara santun kepada orang yang lebih tua, dan lainnya.

Akhlak merupakan yang dapat mendorong perbuatan manusia secara spontan selain sebagai fitrah (naluria) manusia sejak kecil, juga dapat dilakukan melalui kebiasaan latihan dan proses pendidikan sehingga perbuatan-perbuatan itu menjadi baik.

Membiasakan anak untuk berakhlak mulia merupakan solusi terhadap fenomena anak di zaman sekarang yang mengasimilisai budaya asing yang bertentangan dengan aturan Allah Swt. Seperti tidak menghormati orang tua, memakai pakaian serba mini yang memperlihatkan auratnya, dan perilaku lainnya.

Menurut Imam Syed Hafeed al-Kaff (2002: 8), Salah satu kewajiban orang tua adalah menanamkan kasih sayang, ketenteraman, dan ketenangan di dalam rumah. Allah Swt. berfirman:

$$
\text { و من آياته أن خلق لكم من أنفسكم أزو اجا لتسكنوا إليهاو جعل بينكم مودة ورحمة........... }
$$

Artinya: Di antara tanda-tanda kekuasaan-Nya ialah bahwa Ia menciptakan untuk kalian isteri-isteri dari jenis kalian sendiri agar kalian merasa tentram dengan mereka. Dijadikan-Nya di antara kalian rasa kasih dan sayang. (Q.S. ar-Ruum: 21)

Hubungan antara suami dan istri atau kedua orang tua adalah hubungan kasih sayang. Hubungan ini dapat menciptakan ketentraman hati, ketenangan pikiran, kebahagiaan jiwa, dan kesenangan jasmaniah. Hubungan kasih sayang ini dapat memperkuat rasa kebersamaan antaranggota keluarga, kekokohan pondasi keluarga, dan menjaga keutuhannya. Cinta dan kasih sayang dapat menciptakan rasa saling menghormati dan saling bekerja sama, bahu-membahu dalam menyelesaikan setiap problem yang datang menghadang perjalanan kehidupan mereka. Hal ini sangat berperan dalam menciptakan keseimbangan mental anak.

Spock dalam Imam Syed Hafeed (2002: 9) berpendapat bahwa keseimbangan mental anak sangat dipengaruhi oleh keakraban hubungan kedua orang tuanya dan kebersamaan mereka dalam menyelesaikan setiap masalah kehidupan yang mereka hadapi. Suami isteri harus berusaha memperkuat tali kasih di antara diri mereka berdua dalam semua periode kehidupan mereka, baik sebelum masa kelahiran anak mereka maupun setelahnya.

Allender dan Spradley (2005), serta Friedman (1998) mengatakan bahwa fungsi keluarga adalah memberi cinta kasih sayang dan dukungan emosional kepada anggota keluarganya. Pemberian ini secara kontinyu agar terjadi keharmonisan dalam keluarga. Begitu juga hubungan anak didik dengan guru di sekolah.

Seorang ibu hendaknya berusaha keras mengasuh dan memberi kepuasan cinta kasih pada anaknya, misalnya dengan sering mengelus kepalanya sebagai ungkapan rasa cinta. Para ayah juga harus memperhatikan kebutuhan cinta kasih anak-anaknya, mendudukkan mereka di pangkuannya atau di sebelahnya sebagai tanda kasih terhadap mereka.

Seorang Psikolog dan Peneliti Mesir, Sayyid Muhammad Ghanim mengamati bahwa ada empat teori tentang analisa perkembangan kejiwaan dan emosi anak. Yaitu teori 
perkembanan seksual menurut Freud, teori perkembangan sosial menurut Erickson, teori perkembangan identitas menurut Albert, dan yang terakhir teori perkembangan kognitif menurut Piaget. Yang terpenting dari empat pandangan ini, semua sepakat bahwa memerlukan perhatian psikologis dan kasih sayang dari kedua orang tua sejak dini (Mazhahiri, 2000: 202). Kasih sayang inilah yang sebenarnya mampu membina kepribadian anak. Ia dapat tumbuh besar baik secara fisik maupun psikis, sehingga ia mampu menjadi anak yang sesuai dengan harapan agama dan orang tua.

\section{Pola Asuh Anak dalam Perspektif Pendidikan Islam}

Keluarga merupakan insitusi terkecil dalam masyarakat, yang terdiri atas ayah, ibu, dan anak. Keluarga menjadi tempat belajar, dan proses pertumbuhan dan perkembangan anak sebagai manusia yang utuh dan makhluk sosial. Sebagaimana Rasul bersabda:

Artinya: Ibu adalah tempat belajar yang pertama. (al-Hadits)

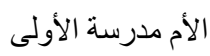

Kata "al-Ummu" di atas menunjukkan ibu sebagai orang yang paling dekat kepada anak dan paling berperan dalam mengasuh atau mendidik anak. Dengan kata lain, ibu sebagai panglima utama dalam mendidik anak, namun ayah juga ikut membantu ibu dalam mendidik anak. Selanjutnya kata "madrasatu al-ula" menunjukkan sebagai tempat anak menerima pendidikan yang pertama dari ibu sebelum ia berinteraksi dengan masyarakat.

Orang tua saat ini menerapkan berbagai pola dalam mengasuh anak seperti dengan lemah lembut, masah bodoh, membebaskan anaknya, dan yang paling mengerikan adalah dengan kekerasan. Pola asuh orang tua sangat mempengaruhi mental dan kepribadian anak. Selanjutnya orang tua perlu mempelajari bagaimana cara mendidik yang baik sesuai dengan usia anak terutama cara mendidik anak yang telah dipraktikkan oleh Rasulullah Saw.

Mendidik dengan baik dan benar berarti menumbuhkembangkan totalitas potensi anak secara wajar. Pola asuh pun menjadi awal perkembangan pribadi dan jiwa seorang anak. Pola asuh adalah tata sikap dan perilaku orang tua dalam membina kelangsungan hidup anak, pertumbuhan, dan perkembangannya; memberikan perlindungan anak secara menyeluruh baik fisik, sosial, maupun mental, serta spiritual yang berkepribadian (Achir, 1989).

Menurut Edwards (2006), pola asuh merupakan interaksi anak dan orang tua dalam mendidik, membimbing, mendisplinkan, dan melindungi anak untuk mencapai kedewasaan sesuai dengan norma-norma yang ada dalam masyarakat". Pola asuh adalah sekelompok sikap yang ditujukan kepada anak melalui suasana emosional yang diekspresikan (Darling dan Steinberg, 1993).

Pola asuh merupakan segala bentuk interaksi antara orang tua dan anak mencakup ekspresi orang tua terhadap sikap, nilai-nilai, minat dan kepercayaan serta tingkah laku dalam merawat anak. Interaksi ini baik langsung atau tidak langsung berpengaruh terhadap anak dalam mendapatkan nilai-nilai dan keterampilan yang akan dibutuhkan untuk hidupnya. Pemahaman terhadap pola asuh merupakan suatu keharusan bagi orang tua. 
Perilaku mengasuh dan mendidik anak sudah menjadi pola yang sadar tidak sadar keluar begitu saja ketika menjadi orangtua. Oleh beberapa peneliti, perilaku-perilaku ini kemudian di teliti dan muncullah beberapa teori untuk menyimpulkan pola-pola pengasuhan yang berkembang. Berikut empat tipe pola asuh yang dikembangkan pertama kali oleh Diana Baumrind (1997) dalam Uswatun Hasanah (2012: 34-37) yaitu: pola asuh authoritative (demokratis); authoritarian (otoriter); permisif; dan uninvolved (penelantar).

Pertama, pola asuh demokratis adalah pola asuh yang memprioritaskan kepentingan anak, akan tetapi tidak ragu-ragu mengendalikan mereka. Orang tua dengan pola asuh ini bersikap rasional, selalu mendasari tindakannya pada rasio atau pemikiran-pemikiran. Orang tua tipe ini juga bersikap realistis terhadap kemampuan anak, tidak berharap yang berlebihan yang melampaui kemampuan anak. Orang tua tipe ini juga memberikan kebebasan kepada anak untuk memilih dan melakukan suatu tindakan, dan pendekatannya kepada anak bersifat hangat.

Kedua, pola asuh otoriter sebaliknya cenderung menetapkan standar yang mutlak harus dituruti, biasanya dibarengi dengan ancaman-ancaman. Misalnya, kalau tidak mau makan, maka tidak akan diajak bicara. Orang tua tipe ini juga cenderung memaksa, memerintah, menghukum. Apabila anak tidak mau melakukan apa yang dikatakan oleh orang tua, maka orang tua tipe ini tidak segan menghukum anak. Orang tua tipe ini juga tidak mengenal kompromi, dan dalam komunikasi biasanya bersifat satu arah. Orang tua tipe ini tidak memerlukan umpan balik dari anaknya untuk mengerti mengenai anaknya.

Ketiga, pola asuh permisif atau pemanja biasanya meberikan pengawasan yang sangat longgar. Memberikan kesempatan pada anaknya untuk melakukan sesuatu tanpa pengawasan yang cukup darinya. Mereka cenderung tidak menegur atau memperingatkan anak apabila anak sedang dalam bahaya, dan sangat sedikit bimbingan yang diberikan oleh mereka. Namun orang tua tipe ini biasanya bersifat hangat, sehingga seringkali disukai oleh anak.

Keempat, tipe penelantar. Orang tua tipe ini pada umumnya memberikan waktu dan biaya yang sangat minim pada anak-anaknya. Waktu mereka banyak digunakan untuk keperluan pribadi mereka, seperti bekerja, dan juga kadangkala biayapun dihemat-hemat untuk anak mereka. Termasuk dalam tipe ini adalah perilaku penelantar secara fisik dan psikis pada ibu yang depresi. Ibu yang depresi pada umumnya tidak mampu memberikan perhatian fisik maupun psikis pada anak-anaknya.

Keempat pola asuh di atas merupakan pola yang sering terjadi dalam keluarga khususnya mendidik anak. Namun yang paling menjadi perhatian saat ini adalah pola asuh otoriter yang identik dengan kekerasan, ancaman, serta kurangnya kasih sayang pada anak. Pola ini terjadi karena adanya ketidakharmonisan keluarga atau ketidaktahuan orang tua bahwa ini akan membahayakan terhadap kepribadian dan mental anaknya.

Mayasari Oei dalam Karlina Silalahi dan Eko (2010), setiap orang tua pasti menginginkan anak-anaknya menjadi manusia yang pandai, cerdas, dan berakhlak. Akan tetapi banyak orang tua yang tidak menyadari bahwa cara mereka mendidik membuat anak 
merasa tidak diperhatikan, dibatasi kebebasannya, bahkan ada yang merasa tidak disayang oleh orang tuanya. Banyak orang tua menganggap pola asuh otoriter yang biasa berwujud dalam bentuk tindakan kekerasan pada anak adalah wajar sebagai cara mendisiplinkan anak. Padahal, anak yang mendapat perlakuan dan asuhan yang keras dan tanpa afeksi, akan mengakibatkan luka batin dalam jiwa si anak.

Kekerasan yang dilakukan oleh orang tua kepada anaknya terjadi karena ketidaktahuan tentang pola asuh atau tekanan dari luar yang membuat ia melakukan hal tersebut. Seperti ia ingin anaknya menjadi seperti anak tetangganya yang cerdas dan baik atau dikarenakan kurang harmonist antara ayah dan ibu.

Menurut Singgih D. Gurnasa dalam Jalaluddin (2002: 104-106), hambatan yang menjadi kendala dalam pendidikan anak di rumah tangga ada enam macam, di antaranya yaitu: yaitu kurang rasa kasih sayang dan pertentangan antara kedua orang tua. Kurangnya kasih sayang akan berdampak pada anak menjadi rendah diri, tidak senang di rumah, tidak senang bekerja sama. Dan pertentangan antara kedua orang tua akan berdampak pada anak akan memihak kepada ayah atau ibu; cemas dan ragu; dan mengalami kegoncangan batin dan sulit menentukan pilihan.

Orang tua memiliki tanggung jawab yang besar mengenai pendidikan anak di dalam keluarga. Karena anak yang dilahirkan dari rahim ibu bagaikan kertas kosong yang dikenal dengan teori "tabularasa" oleh John Locke. Artinya anak siap menerima pengaruh dari luar berupa pendidikan dari orang tuanya. Dalam Islam dikenal dengan istilah "fitrah" yaitu suci.

Islam sebagai agama rahmatan lil 'alamin menawarkan langkah-langkah mendidik anak yang menjadi solusi dalam keluarga sesuai dengan petunjuk al-Qur'an dan al-Hadits. Sebagaimana Rasulullah bersabda:

"Bimbinglah anakmu dengan cara belajar sambil bermain pada jenjang usia 0-7 tahun, dan tanamkan sopan santun dan disiplin pada jenjang usia 7-14 tahun, kemudian ajaklah bertukar pikiran pada jenjang usia 14-21 tahun, dan sesudah itu lepaskan mereka untuk mandiri.

Pernyataan Rasul di atas, setiap jenjang usia anak dianjurkan menerapkan pola mendidik yang berbeda sesuai dengan usia dan potensinya. Hal ini penting diperhatikan oleh orang tua yang menginginkan tumbuh kembang anak yang efektif dan baik. Selanjutnya, tanggung jawab mendidik anak relatif panjang hingga usia 21 tahun. Penjelasan cara mendidik anak sesuai jenjangnya sebagai berikut:

\section{a. Membimbing anak usia 0-7 tahun}

Dalam ilmu jiwa perkembangan, usia 0-7 yahun mencakup masa bayi dan masa kanak-kanak. Menurut Jaka (1979) dalam Jalaluddin (2002: 111), masa bayi merupakan periode pertama yang dilalui bayi setelah dilahirkan. Dalam tahun-tahun pertama perkembangannya boleh dikatakan bayi sangat tergangung dengan lingkungannya. Seroang bayi masih memerlukan perawayan yang telaten. Sedangkan kemampuan yang dimilikinya baru terbatas pada gerak-gerak pernyataan seperti 
menangis dan meraban (mengeluarkan suaran tanpa makna), serta mengadakan reaksi terhadap perangsang dari luar.

Belajar sambil bermain dinilai sejalan dengan tingkat perkembangan anak-anak usia 0-7 tahun. Bimbingan yang diberikan dilakukan dalam suasana ramah, riang gembira dan penuh kasih sayang. Sebagai contoh, umpamanya seorang ayah dan ibu akan membimbing anaknya agar anak mencuci tangan sebelum makan, makan dan minum pakai tangan tangan sebagai bagian dari pendidikan kebersihan dapat dilihat dari rangkaian kalimat berikut:

Ayah: Aduh, anak ayah sudah pintar, sudah bisa makan sendiri.

Ibu : Iya, Amin memang sudah pintar. Anak Ibu ynag manis kalau makan biasanya cuci tangan dulu.

Ayo, Ibu mau lihat. Nah, ini tangan manisnya. Ayo kita cuci dulu, ya?

Kalimat-kalimat pendek seperti itu lebih mudah dipahami anak. Selain itu sesuai dengan tingkat usianya, anak-anak memang bersifat sugestibel (mudah dipengaruhi), terutama jika dengan cara yang baik dan ramah. Bagi anak baik identik dengan bagus. Maksudnya, anak akan menurut kepada seseorang yang menurut penilaiannya baik terhadapnya, karena dalam pandangan anak perlakuan yang baik samalah dengan suatu yang bagus (Jalaluddin: 2002: 113).

Pola asuh seperti ini membutuhkan ketelatenan dari kedua orang tua, mereka harus sabar dan serasi dalam mendidik anak. Anak pada usia ini layaknya seorang "raja" sehingga anak mendapatkan rasa aman, perlindungan yang utuh, sehingga timbul rasa senang dan senang sebagai dasar otak anak dalam proses menerima informasi yang paling efektif.

Pada usia ini, orang tua mulailah sedikit demi sedikit mengenalkan sosok teladan dalam kehidupan mereka seperti Rasulullah Saw., Khulafaur Rasyidin. Tentunya dengan pendekatan yang sesuai dengan usianya. Misalnya makan pakai tangan tangan yang dicontohkan oleh Rasulullah Saw.

Pemberian kasih sayang pada usia ini sangatlah dianjurkan oleh Islam. Kasih sayang yang diberikan orang tua dengan sepenuh hati, maka ia akan menerima kasih sayang dari anak-anak mereka. Rasulullah dalam banyak hal mempraktikkan dalam membimbing anak dengan kasih sayang.

Pada suatu hari, ketika Rasul Saw. tengah mengucapkan khotbahnya, beliau melihat kedua cucunya berlari dengan mengenakan pakaian yang menarik, melihat hal itu Rasul menyempatkan diri turun dari mimbar, membawa keduanya ke mimbar dan melanjutkan khotbahnya dengan menyertakan cucu beliau berada dalam pangkuan. Demikian pula saat Rasul Saw. sedang mengerjakan salat. Saat sujud kedua cucu beliau Hasan dan Husein berada di punggung beliau. Rasul melamakan waktu sujud beliau. Dan setelah keduanya turun, barulah Rasul Saw. menyelesaikan sujud beliau. Terlihat benar kasih sayang Rasul Saw. kepada keduanya. 
Bimbingan dan pendidikan yang didasarkan atas rasa kasih sayang anak membuat anak merasa tidak dikekang, kebebasan akan mendorong anak-anak berkreasi sejalan dengan kemampuan yang mereka miliki.

\section{b. Membimbing anak usia 7-14 tahun}

Pada tahap kedua, Rasul Saw. menyatakan bahwa bimbingan yang diberikan kepada anak dititikberatkan pada pembentukan disiplin dan akhlak (Addibuu). Pada tahap kedua ini, yaitu anak antara usia 7-14 tahun, memang memiliki ciri-ciri perkembangan yang berbeda dari tingkat usia sebelumnya. Ada beberapa aspek perkembangan yang dimiliki oleh anak-anak dalam usia tersebut baik meliputi perkembangan intelektualnya, perasaan, bahasa, minat, sosial, dan lainnya.

Masa ini termasuk masa yang sangat sensitif bagi perkembangan kemampuan berbahasa, cara berpikir, dan sosialisasi anak. Di dalamnya terjadilah proses pembentukan jiwa anak yang menjadi dasar keselamatan mental dan moralnya. Pada saat ini, orang tua harus memberikan perhatian ekstra terhadap masalah pendidikan anak dan mempersiapkannya untuk menjadi insan yang handal dan aktif di masyarakatnya kelak.

Menurut hasil penelitian Alfred Binet dan Simon dalam Jalaluddin (2002: 120), anak di usia tujuh tahun telah memiliki kemampuan menyebut kembali tiga bilangan dari lima angka; membedakan antara kiri dan kanan; menunjukkan apa yang kurang pada suatu gambar; pengetahuan tentang mata uang; dan menggambar belah ketupat berdasarkan contoh.

Berdasarkan tingkat perkembangannya, anak-anak usia 7 tahun memang sudah memiliki kemampuan dasar untuk berdisiplin. Karenanya dalam batas-batas tertentu mereka pun sudah mampu meredam perasaan yang tidak menyenangkan dirinya, untuk berbuat patuh, menurut ketentuan yang dibebankan kepada mereka. Dalam konteks perkembangan ini pula tampaknya anjuran Rasul Saw. untuk membimbing anak dengan menggunakan addib sebagai kiat yang tepat, dan efektif.

Menurut al-Attas (1987) dalam Jalaluddin (2002: 126-127), adab adalah disiplin tubuh, jiwa dan ruh; disiplin menegaskan pengenalan dan pengakuan dan potensi jasmaniyah, intelektual, dan rohaniyah, pengenalan dan pengakuan atas kenyataan ilmu dan wujud ditata secara hierarkis sesuai dengan berbagai tingkat dan derajatnya.

Salah satu yang ditekankan Rasul Saw. adalah salat. "Perintahkan anakmu salat ketika ia berumur tujuh tahun dan pukullah apabila anak itu telah mencapai usia sepuluh tahun, dan pisahlah tempat tidur mereka". Kata "pukullah" dalam hadits ini, bukanlah bermakna "kekerasan" tetapi "diprioritaskan". Mengajarkan anak tentang salat dimulai dari sedini mungkin, hal ini penting untuk membiasakan atau melatih anak dan juga sebagai identitas kemusliman anak.

Selain itu, anak pada usia ini mulailah dididik untuk bangun pagi, membersihkan tempat tidur, mengenakan pakaian sendiri, puasa dan lainnya. 
Selanjutnya orang tua, mulai membuat aturan-aturan yang mendidik yang disertai dengan hukuman dan hadiah.

Hadits di atas mengisyaratkan bahwa anak pada usia tersebut mulai terbiasa dengan hidup disiplin dan anak sangat mudah terpengaruh dari faktor lingkungan sehingga perlu dibuat tata tertib dalam keluarga dengan memberikan hadiah jika melakukan dan diberikan hukuman jika tidak melakukan atau lalai terhadap aturan.

\section{c. Membimbing anak usia 14-21 tahun}

Bimbingan yang diberikan kepada anak dalam periode perkembangan ini menurut Rasulullah Saw. adalah dengan cara mengadakan dialog, diskusi, bermusyawarah layaknya dua orang teman sebaya. Shohihhu (perlakukanlah seperti teman), anjuran Rasul Saw. jangan lagi mereka diperlakukan seperti anak kecil, tapi didiklah mereka dengan menganggap mereka sebagai seorang teman.

Menurut Crijns (Jalaluddin, 2002: 125-126), di usia antara 7-10 tahun mulai berkembang pada motif (alasan) yang menimbulkan perbuatan itu. Dan di atas usia 10 tahun umumnya anak-anak menghargai sesuatu sudah didasarkan pada alasanalasan batin, namun terkadang belum tepat. Barulah pada usia sekitar 14 tahun, pemahaman mereka tentang kesusilaan meningkat.

Di tahap ini porsi kemandirian harus lebih tinggi. Anak sudah mulai bisa menguji dengan tantangan tantangan dunia luar yang lebih "nyata" dan lebih "keras". Peran orang tua di fase ini adalah sebagai "coaching", sebagai teman berbagi suka dan duka para anak sehingga orang tua tetap dapat mengontrol perkembangan, sosialisasi para anak.

Pada usia ini, anak mulai mengalami gejolak batin untuk mencari jati dirinya yang sebenarnya. Gejolak tersebut ditampilkan melalui tingkah laku negatif maupun positif. Mereka mulai mengenal wanita dalam hidupnya, sering melakukan tindakan asusila yang bertentangan dengan hukum agama maupun norma masyarakat.

Untuk mengantisipasi hal tersebut, orang tua diharapkan selalu berdiskusi dan bertukar pikiran mengenai tingkah laku dalam kehidupan bermasyarakat. Dengan menganggap anak sebagai teman berarti tidak ada yang disembunyikan, semuanya dijelaskan secara terbuka. Karena pada usia ini anak sudah dapat membedakan dan menentukan pilihan mana perbuatan yang negatif dan positif.

Setelah melewati usia ini, barulah orang tua melepas anaknya untuk hidup mandiri dengan tetap mendapat pengawasan dari orang tua. Umur 0-21 tahun, anak telah siap untuk menjadi bagian dari masyarakat yang seutuhnya karena mereka telah diasuh dan dididik dengan kasih sayang, diberikan makanan dan minuman yang halal dan thayyib, dikembangkan potensinya, dan dibekali dengan akhlak mulia.

Orang tua tidak perlu takut atau khawatir ketika anak sudah menginjak usia mandiri jika ia dibimbing dengan pola asuh yang sesuai tuntunan al-Qur'an dan Rasulullah Saw. serta penuh dengan kasih sayang. Begitu juga sebaliknya, orang tua 
yang tidak mengoptimalkan peran dan tanggung jawabnya terhadap anak dalam keluarga yang selama ini mengasuh dengan pola kekerasan, ia akan mendapatkan anaknya yang krisis kepercayaan diri dan akhlak.

\section{Kesimpulan}

Orang tua dalam keluarga memiliki peran dan tanggung jawab terhadap anaknya. Setiap orang tua ingin mempunyai anak yang berkepribadian akhlak mulai atau yang saleh. Untuk mencapai keinginan tersebut, orang tua diharapkan untuk mengoptimalkan peran dan tanggung jawab sebagai orang tua terhadap anaknya.

Peran dan tanggung jawab orang tua dalam keluarga dalam perspektif pendidikan Islam yaitu: memberi teladan; memelihara dengan memberikan makanan dan minuman yang halal dan thayyib serta mengembangkan potensi anak; dan membiasakan anak sesuai dengan perintah sehingga menjadi anak yang berakhlak mulia; memberikan kasih sayang; dan menjaga ketentraman serta ketenangan dalam keluarga.

Mengasuh dan mendidik anak yang dilakukan orang tua dengan berbagai macam pola asuh seperti demokratis; otoriter; permisif; dan penelantar (acuh tak acuh). Pola asuh yang menjadi sorotan saat ini adalah pola asuh otoriter yang identik dengan tanpa kasih sayang, kekerasan, mengengkang anak, dan memaksa. Pola ini akan menjadikan batin anak tersiksa, krisis kepercayaan, potensinya tidak berkembang secara optimal, hingga mengalami trauma dan sebagainya. Pola asuh seperti ini sangat bertentangan dengan ajaran Islam yang mengawali konsep kasih sayang dalam mendidik anak.

Islam sebagai agama solutif terhadap permasalahan yang terjadi dalam keluarga tentang bagaimana mendidik anak sesuai dengan usia dan masa pertumbuhan dan perkembangan anak. Pola asuh ini telah dipraktikkan oleh Rasulullah Saw. Adapun pola asuh tersebut, yaitu: membimbing cara belajar sambil bermain pada jenjang usia 0-7 tahun; menanamkan sopan santun dan disiplin pada jenjang usia 7-14 tahun; dan ajaklah bertukar pikiran pada jenjang usia 14-21 tahun, dan sesudah itu lepaskan mereka untuk mandiri. 


\section{Daftar Pustaka}

Al-Qur'an dan terjemahannya.

Achjar, K. A. (2010). Aplikasi Praktis Asuhan Keperawatan Keluarga. Jakarta: Sagung Seto.

Allender, J.A. dan B. W. Spradley. (2001). Community as Partner, Theory and Practice Nursing. Philadelpia: Lippincott.

Al-Kaff, Syed Hafeed. Pendidikan Anak Menurut Ajaran Islam. Pdf.

Friedman, M. M. (1998). Family Nursing Research Theory and Practice. Aplenton: Connecticut.

Jalaluddin. (2002). Mempersiapkan Anak Saleh. Jakarta: Srigunting.

. (2014). Materi Filsafat Pendidikan Islam di PPs IAIN Raden Fatah Palembang di Kelas Reguler PAI Sore B.

Jus'at, Idrus dan Abas Basuni Jahari. (2000). Review Antropometri Secara Nasional dan Internasional. Bogor.

Kamus Besar Bahasa Indonesia. (2002).

Khasanah, Uswatun. (2012). Hubungan Pola Asuh dan Karakteristik Keluarga dengan Status Gizi pada Anak Usia Sekolah di SD Negeri Kelurahan Tugu Kota Depok (Tesis). Jakarta: Universitas Indonesia Fakultas Ilmu Keperawatan.

Kurniawan, Syamsul dan Erwin Mahrus. (2011). Jejak Pemikiran Tokoh Pendidikan Islam. Yogyakarta: ar-Ruzz Media.

Mazhahiri. (2000). Mendidik Anak. Bandung:

Miskawaih, Ibn. (1967). Tahzib Al Aklaq wa Tathhir A`ra. Kairo: Muassasat Al-Khaniji. Dapat juga dilihat pada http://www.alwarraq.com. Dalam google.com. Diakses pada tanggal 29 Oktober 2014.

Oei, Mayasari. Kekuatan Mendidik Tanpa Kekerasan. dalam Silalahi, Karlina dan Eko A. Meinarno. (2010). Keluarga Indonesia. Jakarta: Raja Grafindo Persada.

Rohayati, E. (2011). PEMIKIRAN AL-GHAZALI TENTANG PENDIDIKAN AKHLAK. Ta'dib, 16(01), 93-112. from http://jurnal.radenfatah.ac.id/index.php/tadib/article/view/56

Suprajitno. (2004). Asuhan Keprawatan Keluarga Aplikasi dalam Praktek. Jakarta: EGC. 